\title{
BUDAYA KOMUNIKASI PADA PENGGUNA MEDIA SOSIAL FACEBOOK DI ERA NEW MEDIA
}

\author{
Siti Ani Munasaroh'1) \\ 1)Universitas Islam Negeri Walisongo Semarang \\ 1) animunasaroh@gmail.com
}

\begin{abstract}
Social media is the main choice in establishing social interactions in cyberspace in this new media era. The Facebook application as one of the contemporary social media is widely used by Digital natives. As a creative generation in using technology, Digital natives use Facebook as a medium of communication today. Facebook users who are increasing and used continuously have formed a habit that eventually becomes a culture of communication. This research is a qualitative research with a constructivist paradigm that uses a virtual ethnographic research approach. Virtual ethnography is an approach that aims to observe behavior patterns, patterns of life and social relations in virtual life in cyberspace. This study is to determine the communication culture of Digital natives on the use of social media Facebook. And to find out the communication culture formed from the use of Facebook by Digital natives.
\end{abstract}

Keywords: Culture, Communication, New Media, Facebook, Digital natives.

\begin{abstract}
Abstrak. Media sosial menjadi pilihan utama dalam menjalin interaksi sosial di dunia maya pada era media baru ini. Aplikasi facebook sebagai salah satu media sosial kekinian banyak digunakan oleh Digital natives. Sebagai generasi kreatif dalam menggunakan teknologi, Digital natives memanfaatkan facebook sebagai media komunikasi saat ini. Pengguna facebook yang semakin meningkat dan digunakan secara terus menerus telah membentuk sebuah kebiasaan yang pada akhirnya menjadi budaya dalam berkomunikasi. Penelitian ini merupakan penelitian kualitatif dengan paradigma konstruktivis yang menggunakan pendekatan penelitian etnografi virtual. Etnografi virtual merupakan pendekatan yang bertujuan untuk mengamati pola-pola perilaku, pola kehidupan dan relasi sosial dalam kehidupan virtual di dunia maya (cyber) Penelitian ini hendak mengkaji tentang, perubahan dan budaya komunikasi Digital natives pada penggunaan facebook di era media baru, sedangkan Tujuan dari penelitian ini adalah Untuk mengetahui budaya komunikasi Digital natives pada penggunaan media sosial facebook. Dan untuk mengetahui budaya komunikasi yang terbentuk dari penggunaan facebook oleh Digital natives.
\end{abstract}

Kata Kunci : Budaya, Komunikasi, Media Baru, Facebook, Digital natives.

\section{PENDAHULUAN}

Perkembangan teknologi informasi dan komunikasi (TIK) terjadi dengan sangat pesat beberapa tahun terakhir ini. Internet sebagai bagian dari perkembangan teknologi menjadi alat komunikasi utama yang sangat diminati oleh masyarakat. hal ini menjadi latar belakang terjadinya perubahan teknologi komunikasi dari penggunaan media konvensional 
menuju media baru yang serba digital. Perkembangan penggunaan media internet sebagai sarana komunikasi menjadi semakin pesat setelah internet mulai dapat diakses melalui telephone seluler dan bahkan kemudian muncul istilah telepon cerdas (smartphone). Smartphone dilengkapi dengan fasilitas yang disediakan untuk memudahkan dalam berinteraksi. Proses komunikasi semakin beraneka macam, seperti chatting, email, sms, mms, browsing serta fasilitas media sosial.

Media sosial berdampak besar pada perubahan terhadap cara seseorang dalam berkomunikasi. Hingga Januari 2021, Indonesia memiliki pengguna internet sebanyak 202,6 juta jiwa, jumlah tersebut meningkat sebanyak 27 juta atau 16 persen dibandingkan tahun sebelumnya (Berita Satu, 2021) Berdasarkan data tersebut, dapat diakatakan bahwa masyarakat Indonesia sangat erat hubungannya dengan penggunaan media sosial. Media sosial seolah-olah menjadi suatu kebutuhan pokok yang harus terpenuhi setiap hari.

Digital natives sebagai generasi yang melek teknologi menggunakan media sosial untuk mengekspresikan dirinya, melakukan interaksi sosial di dunia maya, membentuk sebuah kelompok dan sebuah kegiatan. Aplikasi media sosial yang banyak digunakan oleh digital native adalah facebook salah satunya. Aplikasi facebook media sosial yang digunakan untuk melakukan komunikasi baik personal maupun kelompok, berinterkasi dengan orang asing (stranger), berbagi informasi pada orang terdekat, menyampaikan berita, jual beli, hingga membentuk sebuah kelompok dalam grup. Pada awal tahun 2021 facebook memiliki 1.84 miliyar pengguna aktif di seluruh dunia dan 140 juta pengguna di Indonesia. (Facebook statistik, 2021).

Seiring berjalannya waktu terjadi perubahan konsep mengenai komunikasi pada era media konvensional dan media baru. Konsep komunikasi mulai dari intrapersonal hingga massa telah bergeser. Penggunaan media yang berbeda menjadi tanda terjadinya perubahan pada budaya komunikasi. Pada era media baru, hampir semua sistem informasi telah menjadi digital sehingga hampir semua komunikasi berlangsung di dalam teknologi media. Hal ini berdampak pada munculnya kebiasaan baru dalam budaya berkomunikasi (Straubhaar, 2006).

Holmes dalam (Fauzi, 2017) menyatakan bahwa orang yang hidup dalam information society selain bertemu dan menggunakan teknologi-teknologi informasi dan komunikasi, cara dan tindakan mereka semakin dibingkai oleh teknologi tersebut. Hal ini berdampak pada perubahan budaya komunikasi pada era konvensional menuju era media baru. 
Volume 2 Nomor 2 Juli 2021

Berdasarkan paparan latar belakang diatas, penelitian ini hendak mengkaji tentang, perubahan dan budaya komunikasi Digital natives pada penggunaan facebook di era media baru.

\section{METODE PENELITIAN}

Penelitian ini merupakan penelitian kualitatif dengan paradigma konstruktivis yang menggunakan pendekatan penelitian etnografi virtual. Etnografi virtual merupakan pendekatan yang bertujuan untuk mengamati pola-pola perilaku, pola kehidupan dan relasi sosial dalam kehidupan virtual di dunia maya (cyber). Untuk melakukan eksplorasi terhadap user atau entitas pada pengguna internet biasanya menggunakan pendekatan etnografi virtual. Pendekatan ini menjadi sebuah refleksi terhadap implikasi-implikasi dari komunikasi melalui internet (Nasrullah, 2017) .

Sedangkan teknik pengumpulan data dilakukan dengan wawancara secara online maupun serta observasi melalui melalui pengamatan aktifitas penggunaan fitur-fitur Facebook oleh informan.

\section{KAJIAN TEORITIS \\ Budaya Komunikasi}

Manusia melakukan interaksi satu sama lain dengan tujuan pemenuhan kebutuhan hidup, interaksi ini dikenal dengan istilah komunikasi. Dalam pengembangannya, komunikasi diwarnai dengan berbagai hubungan kekuasaan. Perkembangan fenomena komunikasi tergantung pada seberapa jauh perkembangan sumber komunikasi, yaitu pesan dan informasi (pengetahuan yang ada pada masyarakat), hingga media (teknologi komunikasi) yang ada (Soyomukti, 2016: 12).

Menurut Edward T. Hall dalam (Liliweri, 2002) menjelaskan, bahwa kebudayaan adalah komunikasi dan komunikasi merupakan kebudayaan, hal ini karena hanya manusia yang mempunyai kebudayaan, sedangkan binatang tidak. Melalui komunikasi manusia berusaha dalam memenuhi kebutuhan hidupnya yang artinya bahwa perilaku komunikasi merupakan bagian dari perilaku yang ideal yang dirumuskan dalam norma-norma budaya. Dengan demikian maksud dari kebudayaan adalah komunikasi, karena kebudayaan tidak dapat dipisahkan dengan komunikasi. 
Budaya sebagai cara-cara atau kebiasaan yang digunakan saat berinteraksi di media sosial dengan Digital natives. Istilah Digital natives dipopulerkan oleh Marc Prensky di dalam risetnya yang berjudul Digital natives, Digital Immigrant. Digital natives ini adalah mereka yang lahir di atas tahun 1980. Secara garis besar, Gasser dan Palfrey menyebutkan bahwa Digital natives adalah mereka yang tumbuh ketika teknologi mulai berkembang. Dengan kata lain, mereka hidup di dalam lingkungan yang telah di digitalisasi dan tidak ada lagi sistem analog. Budaya komunikasi yang berlangsung pada Digital natives terbagi menjadi dua: face-to-face commuication (FTF) dan computer-mediated communication (CMC). FTF adalah budaya komunikasi primer Digital natives karena mereka merasa membutuhkan budaya komunikasi tatap muka dan silahturahmi. Oleh karena itu, CMC dijadikan sebagai sebuah komunikasi sekunder yang akan dilakukan ketika Digital natives terhalang oleh ruang dan waktu (Putri, 2020: 256).

Budaya komunikasi pada dasarnya merupakan nilai-nilai yang muncul dari proses interaksi antar individu yang berlangsung secara terus menerus. Sehinga dapat disimpulkan bahwa budaya komunikasi merupakan cara atau proses dalam menyampaikan pesan kepada orang lain yang mengacu kepada adat istiadat atau kebiasaan seseorang untuk mencapai tujuan tertentu. Seiring dengan perkembangan kecanggihan teknologi, budaya komunikasi juga berkembang sangat cepat, penggunaan telpon pintar/smartphone memperoleh informasi dengan mudah dan sesuai keinginan, dapat melakukan komunikasi jarak jauh dengan video call dan tetap melakukan tatap muka meskipun secara tidak langsung.

Budaya komunikasi pada konteks penelitian ini adalah bentuk cara-cara Digital natives berinteraksi di media sosial facebook. Pola interasinya tentu dilandasi dengan nilai-nilai yang telah terkonstruksi di dalam diri Digital natives sebagai sebuah determinasi dari penggunaan teknologi baru

\section{Budaya Siber (Cyberculture)}

Fenomena di ruang siber dan media siber menumbuhkan budaya baru yaitu Budaya siber atau cyberculture. Menurut Nasrullah dalam (Fauzi, 2017) Budaya merupakan nilai-nilai yang muncul dari proses interaksi antar individu yang penerapannya terkait dengan sebuah media. Nilai-nilai tersebut diakui, baik secara langsung maupun tidak, kemudian seiring waktu yang diterapkan dalam interaksi tersebut. Karakteristik dunia virtual dapat menghasilkan efek 


\section{คL-ITTISHOL \\ Jurnal Komunikasi dan Penyiaran Islam}

Institut Agama Islam Sunan Kalijogo Malang

P-ISSN: 2721-964X / E-ISSN: 2721-9631

Volume 2 Nomor 2 Juli 2021

dalam kehidupan ketika berhubungan dengan cyberspace. Cyberspace atau ruang siber dapat dipahami melalui culture dan culture artefact. Dalam kajian budaya, awalnya internet merupakan model komunikasi yang sederhana jika dibandingkan dengan model komunikasi secara langsung atau face to face. Hal ini karena generasi internet menyampaikan pesan atau informasi menggunakan teks atau simbol dalam bentuk tulisan atau emoticon dan secara langsung dapat dipahami oleh kedua belah pihak (Fauzi, 2017).

\section{Media Sosial}

Media sosial merupakan sebuah media online, yang penggunanya dengan mudah berpartisipasi, berbagi, dan menciptakan isi meliputi blog,jejaring sosial, wiki, forum dan dunia virtual. Media sosial juga didefinisikan sebagai media online yang mendukung interaksi sosial, teknologi yang digunakan oleh media sosial berbasis web yang dapat mengubah komunikasi menjadi dialog interaktif.

Andreas Kaplan dan Michael Haenlein dalam (Rafiq, 2020) memberikan pengertian media sosial sebagai "sebuah kelompok aplikasi berbasis internet yang membangun di atas dasar ideologi dan teknologi Web 2.0, yang memungkinkan penciptaan dan pertukaran usergenerated content". Jejaring sosial adalah situs dimana setiap orang bisa membuat web page pribadi, dengan tampilan diri sesuka hati. Kemudian dapat terhubung dengan teman-teman untuk berbagi informasi dan berkomunikasi. Jejaring sosial yang paling umum digunakan oleh masyarakat di seluruh dunia yaitu facebook, twitter, tiktok dan Instagram. Jika media tradisional menggunakan mediacetak dan media broadcast, maka media sosial menggunakan internet.Media sosial mengajak siapapun yang tertarik untuk berkonstribusi dan berpartisipasi dengan memberi feedback secara terbuka, memberi komentar, serta membagi informasi dalam waktu yang cepat dan tak terbatas.

Kaplan dan Haenlein dalam (Rafiq, 2020) mengklasifikasikan berbagai jenis media sosial menjadi enam yaitu :

1. Proyek Kolaborasi. Website memberikan izin pada pengguna atau user-nya untuk dapat mengubah, menambah, atau menghapus berbagai konten yang ada di website ini. misalnya wikipedia.

2. Blog dan Microblog. User bebas mengekspresikan sesuatu di blog yang ia gunakan, seperti curhat ataupun mengkritik kebijakan pemerintah. misalnya blogging. 
3. Konten, pengguna website ini saling membagikan konten-konten media, seperti video, ebook, gambar, dan lain-lain. misalnya youtube, tiktok, dan snack video.

4. Situs Jejaring Sosial Aplikasi yang mengizinkan user untuk terhubung dengan cara membuat informasi pribadi sehingga dapat terhubung dengan orang lain. Informasi pribadi itu bisa seperti foto, video maupun tulisan yang dapat diunggah di feed mereka. misalnya facebook, Instagram, twitter.

5. Virtual Game World, merupakan dunia virtual, yang mereplikasikan lingkungan 3D, dimana user muncul dalam bentuk avatar-avatar yang diinginkan dan dapat berinteraksi dengan orang lain selayaknya didunia nyata, misalnya game online seperti mobile legend, $P U B G$ dan free fire.

6. Virtual Social Word. Yaitu dunia virtual yang penggunanya merasa hidup didunia secara virtual, sama seperti virtual game world, dapat melakuakn interaksi satu sama lain. Namun, Virtual Social World lebih bebas, dan lebih kearah kehidupan, misalnya second life.

\section{New Media}

New Media atau biasa disebut dengan media baru merupakan gabungan dari dua kata yaitu media dan baru. Media sendiri merupakan segala sesuatu yang digunakan untuk menyalurkan informasi dari sumber informasi (informan) kepada penerima informasi (komunikan). Manfaat media yaitu dapat memudahkan sesorang untuk memperoleh sesuatu baik informasi, kebutuhan pokok, Pendidikan, hubungan sosial bahkan hiburan. Sedangkan "baru" adalah sesuatu yang menciptakan inovasi maupun perubahan yang dapat melahirkan sesuatu yang sangat diinginkan orang. Media baru merupakan konsep yang dapat menjelaskan kemampuan media dengan dukungan perangkat digital sehingga dapat mengakses konten kapan saja, di mana saja (everywhere, everytime) yang memberikan kemampuan bagi siapa saja, baik sebagai penerima maupun pengguna untuk berpartisipasi aktif, interaktif, dan kreatif terhadap umpan balik pesan melalui isi media sehingga membentuk komunitas atau masyarakat baru (Liliweri, 2015: 284).

Media baru di definisikan oleh Ron Ricese sebagai teknologi komunikasi yang melibatkan komputer dan jaringan teknologi di dalamnya (baik telepon pintar/ smartphone, PC maupun notebook) memfasilitasi penggunanya untuk berinteraksi antar sesama pengguna ataupun dengan informasi yang diinginkannya. Media baru adalah istilah yang dimaksudkan untuk mencakup kemunculan digital, komputer, atau jaringan teknologi informasi dan 
komunikasi di akhir abad ke-20. Misalnya internet, website, komputer multimedia, permainan komputer, CD-ROMS, dan DVD. Sedangkat perangkat radio, televisi, film, majalah, buku, atau publikasi cetak tidak termasuk dalam media baru (Wikipedia, 2021)

Perbedaan media lama dan media baru terletak pada karakteristiknya. Media lama merupakan komunikasi yang heterogen atau satu arah dan bersifat anonym, komunikan tidak terhubung pada pengguna media dan pemberi informasi (komunikator), dan feedback atau umpan balik bersifat tertunda dan tidak langsung. Sedangkan media baru mempunyai karakteristik kebalikan dari media lama, media baru memudahkan dalam pencarian inforasi yang inigin di dapatkan tidak terbatas pada waktu dan jadwal tertentu, para pengguna (user) dapat terhubung langsung meskipun tidak memungkinkan untuk bersinggungan secara publik. Selain itu media baru juga memiliki karakter utama yaitu: representasi numerik, modularitas, otomatisasi, variabilitas, dan transcoding. Namun Manovich hanya menfokuskan karakteristik media baru pada tiga aspek yaitu:

1. Variabilitas, merupakan salah satu karakteristik utama masyarakat postmodernisme yang menjelaskan bahwa semua orang dapat memproduksi gambar dan suara menurut versi mereka sendiri. Kemungkinan besar Variabilitas dapat terjadi karena digitalisasi di mana semua informasi dikodekan dalam data biner 0 dan 1.

2. Modularity, konsep yang dipahami oleh masyarakat pascaindustri, menjelaskan bahwa media digital memiliki berbagai komponen bersifat diskrit artinya tampak terpisah namun setiap saat dapat disusun atau digabungkan dalam representasi data numerik, dari modularitas inilah orang dapat menciptakan variasi konten. Pendiskrit seperti menampilkan versi yang berbeda dari gambar atau suara yang sama.

3. Transcoding, merupakan proses memungkinkan para pengguna semakin mudah menerjemahkan apa yang dia kerjakan ke dalam format yang berbeda apalagi didukung oleh proses komputerisasi. Manovich mengemukakan bahwa media baru mempunyai dua lapisan yang berbeda, yaitu lapisan budaya dan lapisan computer (Liliweri, 2015: 288).

Teknologi komunikasi yang merupakan bagian dari new media melibatkan komputer, agar mempermudah dan mempercepat mendapatkan informasi dari internet. Karakteristiknya yang mudah di akses yaitu mudah di gunakan dimana saja tanpa melalui komputer baik melalui melalui handphone smartphone, android, maupun tablet.Serta bersifat jaringan yaitu koneksi antar jaringan yang melibatkan keinternet dengan adanya aplikasi-aplikasi yang 
menghubungkan koneksi internet dan sangat interaktif. Salah satu aplikasi yang mendukung penggunaan media baru adalah jejaring sosial facebook, twitter, instagram, tiktok dan lain sebagainya. Dalam aplikasi facebook atau biasa desebut fb terdapat beberapa fitur yang tidak hanya digunakan untuk mengobrol, melihat dan mendengar video namun juga dapat menjalin respon atau feedback secara langsung antar pengguna, respon tersebut dapat menentukan kecepatan dan frekuensi penyajian. Media interaktif memiliki unsur audio-visual (termasuk animasi) dan disebut interaktif karena media baru didesain dapat melibatkan respon pemakai secara aktif.

Berangkat dari penjelasan new media diatas, maka dapat diketahui maanfaat new media adalah sebagai berikut:

1. Arus informasi yang dengan mudah dan cepat diakses dimana saja dan kapan saja.

2. Sebagai Media transaksi jual beli.yang efektif, karena tidak mewajibkan pengguna untuk beesinggungan secara langsung .

3. Sebagai media hiburan misalnya game online, jejaring sosial, streaming video, dll.

4. Sebagai media komunikasi yang efisien. Pengguna dapat berkomunikasi dengan orang yang berada jauh sekalipun, bahkan bertatap muka dengan video conference.

Sedangkan beberapa kekurangan dari New Media yaitu sebagai berikut:

1. Terbukanya informasi menimbulkan kemungkinan pencurian data pribadi. Hal ini dilakukan oleh hacker dengan berbagai tujuan tertentu.

2. Berita bohong (hoax) dan cyber crime atau kejahatan dunia maya semakin beredar luas.

3. Terbukanya arus informasi dan komunikasi dapat membawa virus yang terdapat dalam aplikasi sehingga mudah menyebar.

4. Rasa ketagihan berlebihan atau kecanduan, misalnya saat bermain game online maupun mengakses situs jejaring sosial (Setyawan, 2013).

\section{Sejarah dan Perkembangan Facebook}

Facebook berawal ketika Mark Zuckerberg yang saat itu mahasiswa semester II Harvard University membuat sebuah situs kontak jodoh untuk teman-teman di kampusnya. Situs ini diberi nama Facemash.com. Sistem yang digunakan dalam situs ini yaitu menampilkan foto pasangan (pria dan wanita) kemudian pengguna situs ini akan memilih pasangan mana yang paling hot. Zuckerberg membuat situs ini karena mendapat inspirasi dari situs Hot or Not. 


\section{AL-ITTISHOL \\ Jurnal Komunikasi dan Penyiaran Islam}

Institut Agama Islam Sunan Kalijogo Malang

P-ISSN: 2721-964X / E-ISSN: 2721-9631

Volume 2 Nomor 2 Juli 2021

Berbagai upaya dilakukan Zuckerberg untuk mencari foto-foto rekannya untuk ditampilkan sebagai foto-foto pasangan dalam situs ini. Mulai dari door-to-door meminta foto, hingga membobol akses jaringan komputer kampus demi mendapatkan foto-foto tambahan. Namun aksi ini diketahui pihak kampus dan mereka selanjutnya memblokir situs Facemash.com.

Facebook diluncurkan pada 4 Februari 2004, Facebook merupakan situs jejaring sosial yang didirikan oleh Mark Zuckerberg, seorang lulusan Harvard dan mantan murid Ardsley High School. Awalnya anggotanya dibatasi untuk siswa dari Harvard College. Kemudian dalam dua bulan selanjutnya, keanggotaannya diperluas ke sekolah lain di wilayah Boston (Boston College, Boston University, MIT, Tufts), Rochester, Stanford, NYU, Northwestern, dan semua sekolah yang termasuk dalam Ivy League. Banyak perguruan tinggi lain yang selanjutnya ditambahkan berturut-turut dalam kurun waktu satu tahun setelah peluncurannya. Akhirnya, orang-orang yang memiliki alamat e-mail suatu universitas (seperti: .edu, .ac, uk, dll) dari seluruh dunia dapat juga bergabung dengan situs ini (Muhlis, 2018: 24).

Facebook dilengkapi dengan berbagai fitur-fitur layanan yang dapat dimanfaatkan untuk mempermudah pencarian data. Situs jejaring sosial memiliki aplikasi yang berbeda-beda begitupun dengan Facebook, facebook didesain dengan berbagai fitur pendukung antara lain:

1.Layanan upload foto (photo), Foto dapat diaplikasikan dengan cara mengunggah foto sebagai data pribadi atau publik, jika memiliki foto anggota facebook lain, maka dapat menandai foto tersebut dengan kata kunci (tag) berupa nama anggota tersebut, setelah memberikan kata kunci, foto tersebut akan muncul di album foto orang yang menandainya maupun profil teman yang ditandai. Pengguna facebook dibatasi untuk mengunggah foto, yaitu 60 foto dalam satu album pada tahun pertama, tahun-tahun berikutnya yaitu bulan Mei 2009, pengguna facebook dapat mengunggah 200 foto dalam satu album (Wikipedia, 2021).

2.Video (Video), Aplikasi video merupakan aplikasi yang menyerupai YouTube, Tiktok, Instagram dan lain sebagainya. Video dapat diunggah dalam semua format, dengan mensyaratkan ukuran file video dibawah $100 \mathrm{MB}$, dan tidak lebih dari 20 menit facebook akan mengubah file video tersebut dalam format flash (Flv).

3. Grup (group), fitur grup merupakan fitur yang menggabungkan seseorang dengan kelompok lain yang memiliki tujuan yang sama, seseorang juga dapat membuat kelompok sendiri, grup digunakan untuk diskusi, pengumuman kegiatan, dan sebagainya. Biasanya 
grup digunakan oleh klub, perusahaan, dan organisasi masyarakat yang melibatkan massa, misalnya masyarakat umum, karyawan, anggota, pengguna layanan, pemegang saham atau pelanggan, sehingga facebook dapat menjebatani organisasi, kelompok, dan perusahaan tersebut untuk saling berkoordinasi maupun berkomunikasi.

4. Acara (Event) menu acara adalah fitur yang dapat digunakan untuk mengundang anggota lain dalam acara yang akan diselenggaraka dalam aplikasi ini. Perlu diperhatikan dalam menyelenggarakan acara yaitu dalam mengisi nama acara, kata kunci, kota serta daftar tamu yang diundang, karena mengingat sifat acara tersebut baik formal, semi formal, atau untuk grup tertentu.

5. Pasar (Marketplace) merupakan fitur atau layanan jual beli online sejenis e-bay dan Craigslist, fitur ini memungkinkan anggotanya terhubung dengan orang lain yang akan membeli atau menjual barang, semua transaksi terjadi secara langsung antara seseorang atau anggota. Fitur ini diperkenalkan pada 14 Mei 2007 dengan beberapa kategori; dijual, perumahan, lowongan pekerjaan, dan lain-lain, saat penawaran bisa menyertakan bentuk barang yang tersedia maupun yang dicari, aplikasi pasar tersebut dapat dimanfaatkan oleh semua anggota facebook dan gratis (tidak dipungut biaya).

6. Kiriman (Post) fitur kiriman dapat dimanfaatkan untuk mengirim video, lagu, gambar, dan juga hal-hal lain yang ada dihalaman situs lain, ke halaman profil yang dikirim, apabila mengrim pesan maka dapat membalas atau comment, apabila mengirim gambar maka dapat mengunjungi situs tersebut dengan mengklik "gambar tautan".

7. Catatan (Note) Fitur Facebook Note, tidak berbeda jauh dengan buku harian, pengguna facebook dapat membuat tulisan, gambar, foto, atau file lain dihalaman ini, sehingga catatan yang telah ditulis atau di update dapat dibaca oleh teman-teman di facebook. aplikasi tersebut diperkenalkan pada 22 Agustus 2006.

8. Hadiah (Gift) ini, diluncurkan pada 8 Februari 2007, hadiah yang diberikan secara publik (public) akan muncul di dinding penerima beserta pesannya, jika hadiah diberikan secra pribdi (private), nama pengirim dan pesannya tidak dapat dibaca pengguna lain, semua hadiah (termasuk hadiah pribadi) yang diterima akan ditampilkan di kotak hadiah (terletak disebelah kanan atas dinding profil). Hadiah akan ditandai dengan nama depan pengirim (untuk hadiah publik) atau kata pribadi, pengguna juga bisa mengirim hadiah tanpa nama (Anonymous), tetapi anggota facebook yang bisa melihat profil penerima hadiah, bisa 
melihat hadiahnya, tetapi facebooker penerima hadiah saja yang bisa melihat pesannya (Muhlis, 2018).

\section{HASIL TEMUAN DAN PEMBAHASAN}

Straubhaar dan LaRose memberikan pernjelasan mengenai perubahan konsep komunikasi pada masa analog dan digital, era media konvensional dan media baru. Perubahan ini ditandai dengan penggunaan media yang jauh berbeda, dimana pada era sekarang hampir semua komunikasi berlangsung menggunakan teknologi (Straubhaar, 2006). Digital natives sebagai generasi kreatif akan teknologi, dalam penelitian ini mengalami perubahan cara atau pola berkomunikasi baik komunikasi antarpribadi, komunikasi kelompok maupun komunikasi organisasi.

Pada saat era media konvensional untuk melakukan interaksi dengan seseorang harus bertatap muka atau bertemu langsung secara face to face, namun seiring perkembangan teknologi komunikasi telah merubah pola interaksi dengan memudahkan untuk berinteraksi dengan bantuan telpon genggam maupun telpon rumah. Komunikasi dapat dilakukan dengan panggilan atau berkirim pesan (SMS). Telpon genggam maupun telpon rumah saat ini telah bertransformasi menjadi telpon pintar/smartphone pada era media baru ini. Masyarakat mulai mengganti telpon genggam dengan smartphone karena smartphone dapat menyalurkan informasi secara cepat melalui jaringan internet.

Dalam buku Berkomunikasi Ala Net Generation (Budiargo, 2015) menjelaskan bahwa perkembangan teknologi khususnya computer mediated communication (CMC) dalam hal penggunaan internet telah mengubah sifat manusia secara secara evolutif, yang dulunya memerlukan pertemuan secara fisik dan psikis, menjadi pertemuan secara tidak nyata atau virtual. Pemaparan tersebut sejalan dengan hasil penelitian ini bahwa Digital natives melakukan komunikasi tatap muka hanya ketika diperlukan saja. Adapun kegiatan komunikasi dan interaksi dilakukan melalui computer mediated communication (CMC) seperti email, instant messaging, social media, dan memastikan fasilitas internet melalui smartphone atau PC telah terhubung.

Facebook merupakan aplikasi media sosial yang didalamnya telah dilengkapi fasilitas atau fitur-fitur yang mendukung interaksi dan komunikasi secara virtual. Baik komunikasi secara pribadi maupun kelompok. Digital native mempunyai kekuasaan penuh atas identitas 
yang akan ditampilkan kepada publik melalui pengaturan di akun facebook. Facebook dapat melakukan sending photo, video, berita, marketplace, membuat grup atau event maupun hadiah (gift) yang akan muncul di timeline atau beranda anggota facebook lainnya. Aplikasi ini juga dilengkapi dengan layanan panggilan dan berkirim pesan baik text maupun voice secara pribadi melalui direct message (DM).

Berangkat dari pemaparan diatas, menunjukkan bahwa media sosial Facebook dapat mengkonstruksikan budaya pada generasi agar lebih melek teknologi, sehingga perkembangan teknologi dapat digunakan secara efektif sebagai alat komunikasi, baik secara personal maupun komunitas untuk saling berinteraksi, menjaga hubungan dengan orang lain dan sebagai sumber informasi. Pola komunikasi yang dibangun oleh Digital natives pada penggunaan Facebook yaitu kebebasan dalam interaksi sosial, Digital natives cenderung memilih media dengan fasilitas atau fitur yang lengkap, artinya dia ingin membagikan kabar kepada khalayak ramai juga tetap ingin menjaga privasinya. Hal tersebut dapat dilakukan dengan menggunakan aplikasi media sosial berupa Facebook. para Digital natives memilih Facebook karena selain fitur untuk interaksinya lengkap, Facebook juga merupakan media komunikasi kekinian yang tepat untuk melakukan komunikasi baik secara personal maupun group, seperti keluarga, kerabat dan teman dekat.

Hasil riset mengenai Digital natives menyatakan bahwa mereka lebih banyak hidup dan berkomunikasi di dunia online dari pada dunia offline. Beberapa aspek kehidupan mereka seperti interaksi sosial dan pertemanan dimediasi oleh teknologi digital. Hal ini menyebabkan akses informasi tersebar dengan cepat dan mudah (Gasser, 2008). Pada penelitian ini, nilai kemudahan dalam menyebarkan informasi dianut oleh Digital natives, mereka memanfaatkan media Facebook untuk menyebarkan berbagai berita dan informasi.

Salah satu norma yang dianut oleh generasi internet yaitu kebebasan. Mereka menginginkan kebebasan dalam segala hal yang mereka perbuat, dari kebebasan memilih hingga kebebasan berekspresi. Digital natives memanfaatkan teknologi untuk mengekpresikan diri dan memilih media komunikasi mana yang sesuai dengan kebutuhan mereka. Digital natives atau generasi internet juga senang membuat sesuatu sesuai selera yang biasa disebut dengan kustomisasi. Mereka membuat atau mengubah tampilan media sosial miliknya sesuai selera yang mereka inginkan (Tapscott, 2009). 
Dalam penelitian ini mereka berekspresi mengubah foto profil, foto dinding dan mengisi bio di profil akun facebook mereka. Para pengguna facebook bisa dengan sesuka hati mengisi profil atau biodata mereka tidak berdasarkan profil di dunia nyata. Misalnya menggunakan nama-nama yang kekinian dan bukan nama asli, alamat, Pendidikan, umur yang dipalsukan. Sehingga pengguna facebook benar-benar merasa hidup di dunia maya dengan menggunakan identitas mayanya.

Norma lainnya yang dianut oleh generasi internet adalah hiburan. Mereka membutuhkan suatu hiburan dan kegiatan bermain baik dalam kegiatan pekerjaan, pendidikan dan kehidupan sosial mereka. Digital natives pada penelitian ini membutuhkan pengamatan pada beranda facebook seseorang untuk mengetahui perkembangan tentang status temantemannya. Setiap orang cenderung terbuka akan informasi tentang dirinya di dalam aplikasi facebook dengan mengupdate kegiatan atau perasaan yang dialami akan dirinya pada timeline. Mereka menganggap facebook sebagai sebuah sarana hiburan karena mereka merasa terhibur dengan membaca update yang muncul pada menu timelinnya. Mereka juga menganggap media sosial facebook sebagai sebuah buku diary atau tempat berkeluh kesah, dalam hal ini, pengguna facebook cenderung mengabaikan privasi-privasi yang perlu dijaga dalam dirinya. Dan norma lainnya yang dianut generasi internet adalah kecepatan. Digital natives mengharapkan komunikasi yang sama cepat dari pihak-pihak lain, setiap pesan instan harus menghasilkan tanggapan yang juga instant atau dilakukan secara langsung.

Interaksi yang terjadi di dunia cyber pada kenyataannnya terjadi melalui medium teks. Nasrullah (2014: 83) menjelaskan bahwa ada dua term yang bisa digunakan untuk mendekati bahasa di media cyber "netspeak" yang artinya pembicaraan yang seolah-olah penulisan, "netlingo" yang merupakan bahasa teks baku menjadi bahasa teks yang seolah-olah mewakili ungkapan seseorang ketika berbicara. Dalam penelitian ini netspeak dapat berupa emoticon gambar kuning dengan wajah terseyum, menangis, tertawa, dan lain sebagainya. Selain itu juga dapat berupa tulisan seperti "hahaha", "wkwkwk" "hehehe" yang artinya pembicaraan seolah-olah penulisan. Hal ini menyebabkan munculnya budaya penulisan texting yaitu terbiasa menulis dan berkomunikasi dalam bentuk teks-teks singkat. 


\section{KESIMPULAN}

Berdasarkan hasil pembahasan diatas, dapat disimpulkan bahwa: Bergabungnya teknologi komunikasi berupa smartphone menjadikan teknologi komunikasi di era media baru lebih unggul dibandingkan dengan teknologi komunikasi terdahulu. Facebook merupakan salah satu aplikasi media sosial yang ada di smartphone yang sangat popular di era media baru. Facebook digunakan Digital natives sebagai media komunikasi dilengkapi dengan berbagai fitur yang mampu memberikan banyak kemudahan dan kecepatan untuk berinteraksi.

Dalam penelitian ini Digital natives mengalami beberapa perubahan cara dan pola berkomunikasi dari era media konvensional ke era media. Dalam konteks komunikasi interpersonal, komunikasi kelompok dan komunikasi organisasi yang dilakukan oleh Digital natives, sebelum memasuki era media baru mereka berkomunikasi dilakukan secara langsung atau face to face (CMC). Setelah smartphone diluncurkan semakin memudahkan seseorang untuk berkomunikasi dan berinteraksi satu sama lainnya dengan menggunakan media sosial facebook saja. Dalam komunikasi kelompok atau sebuah organisasi yang dijalaninya, secara konvensional mereka mengutus seseorang untuk menyebar luaskan informasi berupa surat maupun pesan singkat melalui SMS yang dikirim langsung kepada anggota organisasinya kemudian bertemu secara langsung untuk membahas halhal tertentu. Namun pada era media baru saat ini dengan memanfaatkan smartphone dan hanya menggunakan media sosial facebook, pengguna dapat saling terhubung secara langsung melalui jaringan internet.

Media komunikasi dimanfaatkan oleh Digital natives untuk proses suatu interaksi sosialnya, cara berkomunikasi melalui smartphone yang didukung dengan jaringan internet ini disebut computer mediated communication (CMC), digital ative menggunakan media sosial facebook untuk menjalin hubungan sosial dan berbagi informasi baik dalam komunikasi interpersonal, komunikasi kelompok dan komunikasi organisasi. Kebiasaan baru dalam budaya berkomunikasi terjadi akibat penggunaan teknologi smartphone yang terus menerus dijadikan sebagai media komunikasi yang paling efektif. Digital vative mengadopsi nilai kedekatan dan kepraktisan dalam menyebarkan berbagai informasi melalui media sosial facebook Sehingga pada era media baru saat ini generasi internet menganut norma kebebasan, kustomisasi, hiburan dan kecepatan. 
Volume 2 Nomor 2 Juli 2021

\section{DAFTAR PUSTAKA}

Budiargo, D. (2015). Berkomunikasi Ala Net Generation. Jakarta: PT. Elex Media.

Facebook statistik. (2021). Retrieved from https://www.websitehostingrating.com/id/facebookstatistics/

Fauzi, R. (2017). Perubahan Budaya Komunikasi pada Pengguna Whatsapp di Era Media Baru . JIKE Vol. 1 No. 1.

Gasser, J. P. (2008). Born Digital Understanding The First Generation of Digital Natives. New York: Basic Book.

Liliweri, A. (2002). Makna Budaya dalam Komunikasi Antar Budaya. Yogyakarta: LKiS.

Liliweri, A. (2015). Komunikasi Antar Personal. Jakarta: Kencana.

Muhlis, U. J. (2018). Fenomena Facebook sebagai Media Komunikasi Baru . Jurnal Diskursus Islam. Vol. 06 N0.1.

Nasrullah, R. (2014). Teori dan Riset Media Siber (Cybermedia). Jakarta: Kencana.

Nasrullah, R. (2017). Etnografi Virtual. Riset Komunikasi, Budaya dan Sosio Teknologi di Internet. Bandung: Simbiosa Rekatama Media.

Putri, F. A. (2020). Budaya Komunikasi Virtual Pada Masa Pandemi Covid-19 (Studi Kasus Pembelajaran Daring di UIN Walisongo Semarang). JURNAL KOMUNIKA ISLAMIKA: JURNAL ILMU KOMUNIKASI DAN KAJIAN ISLAM Vo. 7 No. 2, 256.

Rafiq, A. (2020). Dampak Media Sosial terhadap Perubahan Sosial Suatu Masyarakat. Global Komunika Vol. 1 No.1.

Satu, B. (2021). Media sosial paling populer. Retrieved from https://www.beritasatu.com/digital/733355/data-ini-media-sosial-paling-populer-diindonesia-20202021

Setyawan, R. (2013). Kekuatan New Media Dalam Membentuk Budaya Populer . eJournal llmu Komunikasi, 1 (2): 355-374.

Soyomukti, N. (2016). Pengantar Ilmu Komunikasi. Cetakan keempat. Jogjakarta: Ar Ruzz Media.

Straubhaar, J. d. (2006). Media Now : Communications Media in The Information Age. Belmont USA: Wadsworth/Thomson Learning.

Tapscott, D. (2009). apscott, Don. 2009. Grown Up Digital : How The Net Generation Changing Your World. iMC Graw Hill.

Wikipedia. (2021, Juni). Wikipedia: Facebook. Retrieved from https://id.wikipedia.org/wiki/Facebook

Wikipedia. (2021). Wikipedia: Pengertian Media baru. Retrieved from https://id.wikipedia.org/wiki/mediabaru 